\title{
A First Record of Exserohilum rostratum as a New Pathogen Causing Bean Blight in Egypt
}

\author{
Farag $\mathrm{MF}^{1^{*}}$, Attia $\mathrm{FM}^{2}$ \\ ${ }^{1}$ Plant Pathology Research Institute, Agricultural Research Center, Giza, Egypt; ${ }^{2}$ Department of Plant Pathology, Faculty of \\ Agriculture, Cairo University, Egypt
}

\begin{abstract}
Seedling blight of bean (Phaseolus vulgaris L.) was recorded in bean fields at five different localities in Beni Sweif Governorate, Egypt. Symptoms appeared as green dark to purplish-brown spots, with brown margins. The affected plant leaves were collected for mycological analysis. Percentage of disease incidence were $30 \%, 25 \%, 22 \%, 15 \%$ and 35\% in El-Wasta, Nasser, Beni Sweif, Sumosta and Beba counties respectively. Leaf samples were surface sterilized and cultured on potato dextrose agar. The growing fungi were identified on morphological as well as on molecular basis. Microscopic examination revealed that the isolated organisms have the same characteristics of Exserohilum rostratum (Drechsler) Leonard \& Suggs. Among the 30 fungal isolates collected from the five bean plantations, a representative isolate was grown for DNA extraction, PCR and rDNA sequencing. Universal primers targeting ITS regions of the rDNA were used for PCR and sequencing. Results confirmed that the sequences of these fungi showed close relationship with E. rostratum with $99.6 \%-100 \%$ similarity. The obtained sequences were deposited in the GenBank with accession numbers MT075801, MT071830, MT071831, MT071832, and MT071834. Pathogenicity tests confirmed that E. rostratum strains were pathogenic showing the same disease symptoms previously observed on bean plants in the study areas. The minimum temperature for spore germination was $5^{\circ} \mathrm{C}$, the optimum temperature was $35^{\circ} \mathrm{C}$, and the maximum temperature was $50^{\circ} \mathrm{C}$. On the other hand, conidial germination was stopped at both lower $\left(3^{\circ} \mathrm{C}\right)$ and higher $\left(55^{\circ} \mathrm{C}\right)$ temperatures. Studying the host range of the fungus showed that the pathogen was able to attack tomato, pepper, squash and potato beside common bean and watermelon.
\end{abstract}

Keywords: Exserohilum rostratum; Temperature; Bean; Symptoms; Pathogenicity; Host range

\section{INTRODUCTION}

Common bean (Phaseolus vulgaris L.) is considered one of the most promising vegetable crops for local consumption as well as exportation. This crop is very important in the daily diet of more than 300 million people worldwide [1]. Bean plants are vulnerable to be attacked by a number of plant pathogens which can cause considerable losses in the yield and reduce the quality of seeds. Bean growers in Beni Sweif Governorate claimed that unknown disease began to attack bean plants just postemergence of the seedlings above soil level up to the harvesting stage causing serious losses. Accordingly, the authors arranged several visits to bean plantations located in the five counties of
Beni Sweif Governorate and performed extensive surveys to determine the disease incidence and to collect diseased specimens for mycological and pathogenicity studies.

The genus Helminthosporium was discovered and classified by Link [2]. The type species, $H$. velutinum, is a saprobic dematiaceous fungus occurring on dead stems of Alnus, Cornus, Salix and numerous other plants. But currently less than 50 species are considered to represent true Helminthosporium species $[3,4]$. Refinements in the taxonomy of this genus resulted in there allocation of many of its members to other genera such as Alternaria, Corynespora, Dendryphion, Septonema and others [5].

\footnotetext{
"Correspondence to: Farag MF, Plant Pathology Research Institute, Agricultural Research Center, Giza, Egypt, Tel: 01110016378; E-mail: Dr.farag_mohamed@yahoo.com
}

Received date: April 28, 2020; Accepted date: May 22, 2020; Published date: May 29, 2020

Citation: Farag MF, Attia FM (2020) A First Record of Exserohilum rostratum as a New Pathogen Causing Bean Blight in Egypt. Plant Pathol Microbiol. 11: 496. doi: 10.35248/2157-7471.20.11.496.

Copyright: () 2020 Farag MF, et al. This is an open-access article distributed under the terms of the Creative Commons Attribution License, which permits unrestricted use, distribution, and reproduction in any medium, provided the original author and source are credited. 
Later, Shoemaker [6] erected Bipolaris for taxa previously accommodated in Eu-Helminthosporium bipolaris was a heterogeneous entity which included two subgroups based on differences of the hilum morphology and associated with two different sexual morphs. The group that has conidia with nonor slightly protruding hila was often associated with the sexual morph Cochliobolus, characterised by filiform ascospores that often appear more or less coiled in a helix within the ascus [7-11]. On the other hand, the group that has conidia with a protruding hilum had sexual morphs with fusoidascospores enveloped in gelatinous sheaths, which was originally described in Trichometasphaeria [12-14]. Later Leonard \& Suggs [15] erected Exserohilum to accommodate those Bipolaris s.lat. species with a distinctly protruding hilum, and Setosphaeria for the sexual morph. Setosphaeria differs from Trichometasphaeria by the production of non-clypeateascomata which can be erumpent or superficial and produce larger ascospores.

Rossman et al. [16] recommended the name Exserohilum over Setosphaeria according to Article 57.2 of the International Code of Nomenclature for algae, fungi and plants [17]. MycoBank currently lists 38 taxa in Exserohilum, most of which are associated with diseases of grasses [18,19]. Exserohilum species attacking economically relevant crops include E. pedicellatum (causing root rot of maize and brown lesions on wheat roots), E. prolatum (producing leaf spots on maize), and E. rostratum (associated with leaf spot and foot rot of wheat, damping off of sugarcane seedlings, leaf spot of banana, and blackening and seed germination failure in many cereals) [20].

In Egypt as well as in other countries, no previous investigations were found in the available literature concerning bean blight therefore the present study was planned to shed lights on this disease and the causative pathogen. Experiments were run for isolation and identification of the causative fungus. The work was also expanded to study the pathogenic potentialities of the isolated fungus and its host-range.

\section{MATERIALS AND METHODS}

\section{Disease survey in commercial bean fields}

A total of 20 fields cultivated with bean were surveyed for bean blight during the growing seasons from October to December 2019 and February to April 2020. The incidence of plants showing typical disease symptoms was assessed in 10 randomly selected groups of 10 consecutive plants amounting to 100 plants/field. Incidence values were used to calculate a disease index. Percentage of disease incidence was recorded as the number of diseased plants relative to the number of growing plants for each treatment, and then the average of disease incidence was calculated.

\section{Sample collection and fungal isolation}

Samples of infected bean plants were collected from thirty sampling locations during the planting season throughout Beni Sweif Governorate, Egypt. Fungi from leaf samples were isolated on potato dextrose agar medium (PDA) supplemented with an antibacterial antibiotic as described by Pitt and Hocking [21].
Spore suspension from each fungal isolate was streaked onto autoclaved 4\% water agar (WA), and was then incubated for 24 h. at $28^{\circ} \mathrm{C}$. A growing hyphal tip from a single spore was cut and transferred onto new PDA. Pure cultures of the fungus isolates were sub cultured and maintained as a conidial suspension in sterile $25 \%$ glycerol of water at $-10^{\circ} \mathrm{C}$.

\section{Phenotypic characterization of fungal isolates}

The obtained isolates were identified macroscopically and microscopically on PDA. Macroscopic characteristics included colony features, color, and growth rate while microscopic characteristics included conidial shape and size using a microscope (Carl Zeiss, Germany). Morphological characterization was completed as described by Domsch et al. [22].

\section{Molecular identification of fungal isolates}

Fungal isolates were grown in sterile Petri plates containing autoclaved potato dextrose agar (PDA) medium and incubated for 7 days at $28^{\circ} \mathrm{C}$ [21]. Cultures were sent to the Molecular Biology Research Unit, Assiut University for DNA extraction using Patho-gene-spin DNA/RNA extraction kit provided by Intron Biotechnology Company, Korea. The fungal DNA was then sent to SolGent Company, Daejeon South Korea for polymerase chain reaction(PCR) and rRNA gene sequencing. PCR was performed using ITS1 (forward) and ITS4(reverse) primers which were incorporated in the reaction mixture. Primers have the following composition: ITS1 (5' TCCGTAGGTGAACCTGCG G -3'), and ITS4 (5'TCCTCCGCT TAT TGA TAT GC -3'). The purified PCR products (amplicons) were sequenced with the same primers [23]. The obtained sequences were analyzed using Basic Local Alignment Search Tool (BLAST) from the National Center of Biotechnology Information(NCBI) website. Phylogenetic analysis of sequences was done with the help of MegAlign(DNA Star) software version 5.05 .

\section{Pathogenicity test}

This part of study was conducted at Sids Agricultural Research Station. Seeds ofcommon bean (var. Giza 6) were obtained from horticultural research institute, Giza Governorate. Under greenhouse conditions, seeds were sown in pots $(20 \mathrm{~cm}$ diameter) filled with a sterilized mixture of equal portions $(\mathrm{v} / \mathrm{v})$ of soil, sand and clay (3 seeds/pot). Five isolates of E. rostratum were used for pathogenicity tests on 2 -wk-old bean seedlings. Ten days old cultures were used for inoculation. Inoculums were prepared by washing the conidia from cultures in Petri plates using sterile water with a surfactant, $0.05 \%$ Tween 20 . Conidial suspensions were prepared and adjusted to $1 \times 10^{6}$ spores $/ \mathrm{mL}$ containing $0.05 \%$ Tween 20, and a sterile cell scraper. Fungal suspensions were sprayed onto the leaves of each bean plant. The inoculated plants were then covered with black plastic bags for $48 \mathrm{~h}$ to maintain high humidity. Three replicates of plants were sprayed with each tested isolate; un-inoculated plants served as a negative control. Nine days post-inoculation the same symptoms appeared. Pathogenicity was evaluated with disease incidence after inoculation and disease reaction was rated as described 
before. Re-isolation of the pathogen from inoculated leaves was conducted as previously described. Morphological identification and comparison between the inocula and the re-isolated cultures was confirmed by microscopic examination.

\section{Effect of temperature on conidial germination}

Drops of E. rostratum spore suspension were placed on glass slides. The slides were then placed in moist chambers prepared by placing two moist filter papers in the inner surface of a Petriplate. Three replications were made for each treatment. The slides were incubated at $5^{\circ} \mathrm{C}, 10^{\circ} \mathrm{C}, 15^{\circ} \mathrm{C}, 20^{\circ} \mathrm{C}, 25^{\circ} \mathrm{C}, 30^{\circ} \mathrm{C}$, $35^{\circ} \mathrm{C}, 40^{\circ} \mathrm{C}, 45^{\circ} \mathrm{C}, 50^{\circ} \mathrm{C}$ and $55^{\circ} \mathrm{C}$ for $24-48 \mathrm{hrs}$ and the percentage of germination was calculated under a light microscope.

\section{Host range investigation}

The pathogenicity of E. rostratum strain (AUMC 14371) was tested under greenhouse conditions across 13 plant species covering 4 families, i.e., Solanaceae (tomato, potato, eggplant, and pepper), Fabaceae (bean, cowpea and soybean) Cucurbitaceae (cucumber, watermelon, melon, squash, and cantaloupe) and Brassicaceae (cabbage). Seeds of all the test plants (except potato) were sown in $1 \mathrm{~L}$ pots containing sterilized potting soil mix and distributed on 3 replicates. Potatoes used for host range studies were grown from tuber pieces each with a single shoot. All plants were inoculated at four-leaf stage for larger leaved plants (Cucurbitaceae and Brassicaceae plants) and at eight to ten-leaf stage for small leafy plants (Solanaceae and Fabaceae plants) [24]. Inoculums for all host range experiments were sprayed over the tested plants as described under pathogenicity test. Data were statistically analyzed for computing L.S.D. test at $5 \%$ probability according to the procedure outlined by Snedecor and, Cochran [25].

\section{RESULTS}

\section{Blight symptoms on bean leaves}

Primary symptoms of bean blight appeared on the cotyledonary leaves as green dark to purplish-brown spots. In general, the disease symptoms appear on the above ground parts of bean plant as small irregular lesions, dark green(gray) to dark brown with brown marquis. Later, the lesions enlarge and merge together to infect large areas (Figure 1). Severe infections result in premature defoliation and often caused plant collapse.

\section{Morphological characteristics of fungal isolates}

The isolated fungi showed good growth on PDA medium. Colonies were circular, deep, the color of the colony was smoke grey fading to olivaceous (Figure 2). Conidia are dark brown, cylindrical each with a markedly protruding truncate hilum and 7 to 12 pseudosepta. Conidial dimensions range from 15.0-80.0 $\mu \mathrm{m}$ in length and are 8.0-16.0 $\mu \mathrm{m}$ wide. A dark septum is usually observed at the polar cells of each conidium. Conidiophores erect or slightly curved, septate, geniculate, olivaceous-brown with swollen conidiogenous cells containing circular conidial scars. In the strains AUMC 14371, AUMC 14372, AUMC
14373, and AUMC 14374 compared with strain AUMC 14375 was tallest and dark brown which isolated from Beba County. Conidia germinate predominantly from the two opposite poles (Figure 3) and occasionally from intermediate cells. These morphological characteristics are consistent with those of Exserohilum rostratum (Drechsler) Leonard \& Suggs.

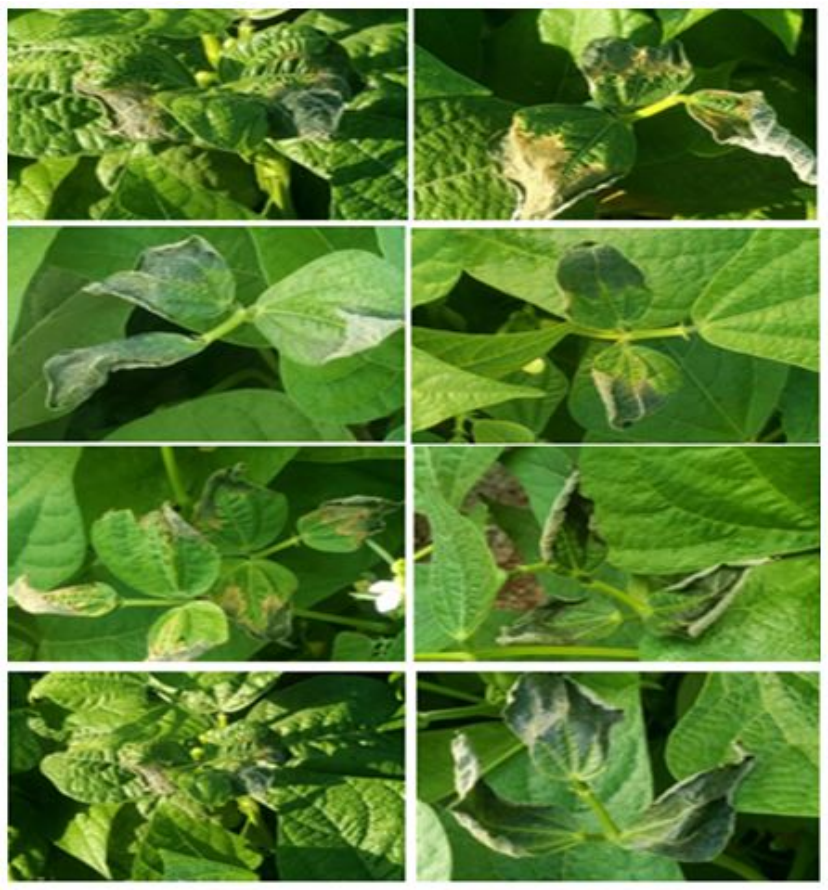

Figure 1: Blight symptoms on bean leaves infected with E. rostratum isolates. Lesions varied from dark green (gray) to brown, with brown margins on the leaves.

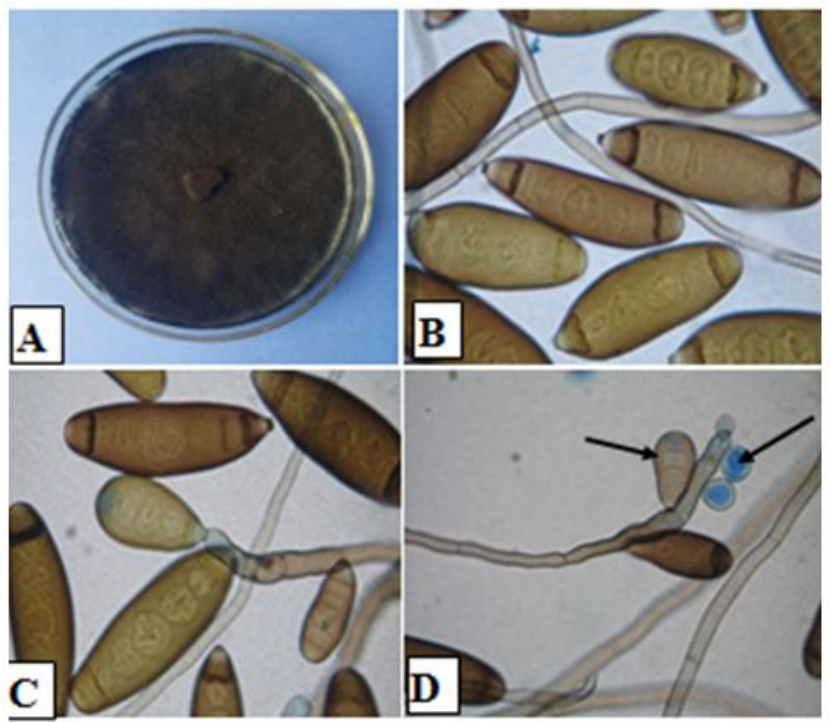

Figure 2: Exserohilum rostratum: Colony on PDA at $35^{\circ} \mathrm{C}$ after 5 days (A); Mature conidia of strain AUMC 14371 (B and C 400x), Pre mature spores emerge from the tip of the conidiogenous cell (arrowed D 200x). 


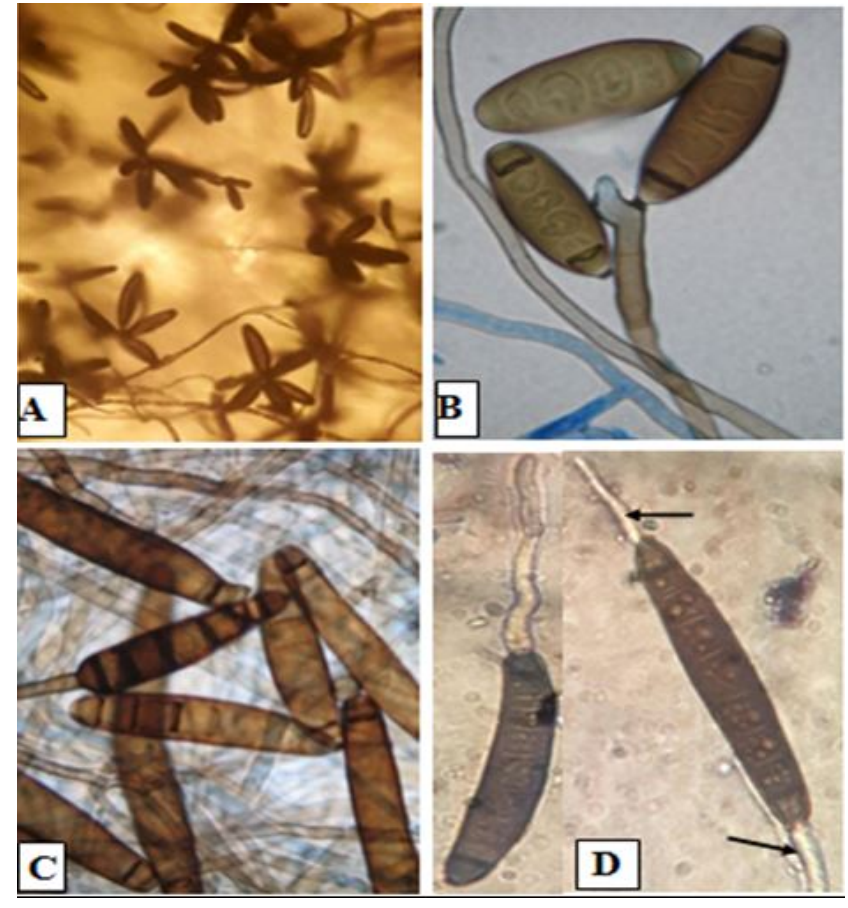

Figure 3: Exserohilum rostratum: Conidia on the conidiophores of strain AUMC 14374(A 100x), Conidia of strain AUMC 14371(B 400x), Spores on conidiophores of strain AUMC 14375(C), and Bipolar conidial germination(arrowed D 400x).

\section{Disease survey in commercial fields}

An accurate extensive survey of blight was carried out on bean plantations during 2019 and 2020 at Beni Sweif Governorate. The inspected counties were El- Wasta, Nasser, Beni Sweif, Sumosta and Beba. In general, the percentages of disease incidence on bean plants during 2020 season were much higher than those recorded during 2019 season while the reverse was recorded for Beba county was record the opposite. Data obtained during the season of 2019 revealed that the highest infection on bean was recorded at Beba, being 35\%. However, during the season of 2020 the highest disease incidence on bean plants was recorded at El-Wasta County, being 35\%, in Table 1.

Table 1: Evaluation the disease incidence of bean seedling blight (E. rostratum) in different counties of Beni Sweif governorate during the two growing seasons 2019 and 2020.

\begin{tabular}{lll}
\hline \multirow{2}{*}{ County } & \multicolumn{2}{c}{ Disease incidence (\%) } \\
\cline { 2 - 3 } & 1st season & 2nd season \\
\hline El-Wasta & 30 & 35 \\
\hline Nasser & 25 & 27 \\
\hline Beni Sweif & 22 & 24 \\
\hline Beba & 35 & 32 \\
\hline Sumosta & 15 & 20 \\
\hline L.S.D. at 0.05 & 4.8 & 5.4 \\
\hline
\end{tabular}

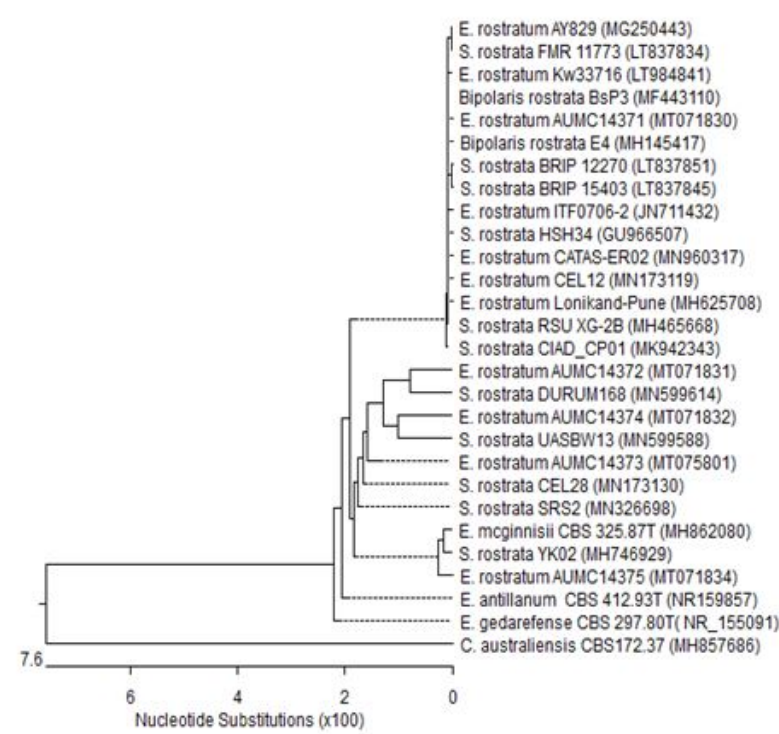

Figure 4: Phylogenetic tree based on ITS sequences of rDNA of the fungal strains isolated in the present study (AUMC No. 14371, 14372, 14373, 14374 and 14375) aligned with closely related sequences accessed from the GenBank. These isolates showed 99.65\% - 100\% similarity with several strains of Bipolaris rostratum Exserohilum rostratum and Setosphaeriarostrata. Curvularia australiensis is included as an out group strain. (E. = Exserohilum, S. = Setosphaeria, GenBank accession Numbers are shown between parentheses).

Five isolates representing the five counties at Beni Sweif governorate were selected for molecular studies. Molecular identification of the five isolates, i.e., AUMC 14371,AUMC 14372, AUMC 14373, AUMC 14374 and AUMC 14375 was confirmed using the internal transcribed spacer (ITS) region of ribosomal DNA, amplified with universal primers ITS1/ITS4, and sequenced directly. An NCBI-BLAST search showed the greatest identity (100\% similarity) with the ITS sequences of Exserohilum rostratum. The sequences were deposited in NCBI GenBank with accession numbers MT071830, MT071831, MT075801, MT071832 and MT071834 respectively. Based on microscopic, morphological, and molecular characteristics, the fungal isolates were identified as Exserohilum rostratum. Representatives of closely related strains of E. rostratum are included in the phylogenetic tree Figure 4.

\section{Exserohilum rostratum AUMC 14371 (MT071830) (Length: 598)}

TAGGTGAACCTGCGGAGGGATCATTACACAACAAAAAT ATGAGGGTGTGGTTTGCTGGCAACAGCGTCCGCCCC AAGTATTTTTCACCCATGTCTTTTGCGCACTTTTTGTTT CCTGGGCGAGTTCGCTCGCCACCAGGACCCAACCATA AACCTTTTTTTATGCAGTTGCAATCAGCGTCAGTATAAT AATTCAATTTATTAAAACTTTCAACAACGGATCTCTTGG TTCTGGCATCGATGAAGAACGCAGCGAAATGCGATAC GTAGTGTGAATTGCAGAATTCAGTGAATCATCGAATCT TTGAACGCACATTGCGCCCTTTGGTATTCCAAAGGGC ATGCCTGTTCGAGCGTCATTTGTACCCTCAAGCTTTGC 
TTGGTGTTGGGCGTCTTTTTGTCTCTCCCCTTGTTGG GGGAGACTCGCCTTAAAACGATTGGCAGCCGACCTAC TGGTTTTCGGAGCGCAGCACAAATTTGCGCCTTCCAA TCCACGGGGCGGCATCCAGCAAGCCTTTGTTTTCTAT AACAAATCCACATTTTGACCTCGGATCAGGTAGGGATA CCCGCTGAACTTAAGCATATCAATAAGCGGAGGA

\section{Exserohilum rostratum AUMC 14372 (MT071831) (Length: 577)}

TGCGGAGGGATCATTACACAACAAAAATATGAGGGTGT GGTTTGCTGGCAACAGCGTCCGCCCCAAGTATTTTTC ACCCATGTCTTTTGCGCACTTTTTGTTTCCTGGGCGAG TTCGCTCGCCACCAGGACCCAACCATAAACCTTTTTTT ATGCAGTTGCAATCAGCGTCAGTATAATAATTCAATTTA TTAAAACTTTCAACAACGGATCTCTTGGTTCTGGCATC GATGAAGAACGCAGCGAAATGCGATACGTAGTGTGAA TTGCAGAATTCAGTGAATCATCGAATCTTTGAACGCAC ATTGCGCCCTTTGGTATTCCAAAGGGCATGCCTGTTC GAGCGTCATTTGTACCCTCAAGCTTTGCTTGGTGTTG GGCGTCTTTTTGTCTCTCCCCTTGTTGGGGGAGACTC GCCTTAAAACGATTGGCAGCCGACCTACTGGTTTTCG GAGCGCAGCACAAATTTGCGCCTTCCAATCCACGGGG CGGCATCCAGCAAGCCTTTGTTTTCTATAACAAATCCA CATTTTGACCTCGGATCAGGTAGGGATACCCGCTGAA CTTAAGCATATCAA

\section{Exserohilum rostratum AUMC 14373 (MT075801) (Length: 577)}

TGCGGAGGGATCATTACACAACAAAAATATGAGGGTGT GGTTTGCTGGCAACAGCGTCCGCCCCAAGTATTTTTC ACCCATGTCTTTTGCGCACTTTTTGTTTCCTGGGCGAG TTCGCTCGCCACCAGGACCCAACCATAAACCTTTTTTT ATGCAGTTGCAATCAGCGTCAGTATAATAATTCAATTTA TTAAAACTTTCAACAACGGATCTCTTGGTTCTGGCATC GATGAAGAACGCAGCGAAATGCGATACGTAGTGTGAA TTGCAGAATTCAGTGAATCATCGAATCTTTGAACGCAC ATTGCGCCCTTTGGTATTCCAAAGGGCATGCCTGTTC GAGCGTCATTTGTACCCTCAAGCTTTGCTTGGTGTTG GGCGTCTTTTTGTCTCTCCCCTTGTTGGGGGAGACTC GCCTTAAAACGATTGGCAGCCGACCTACTGGTTTTCG GAGCGCAGCACAAATTTGCGCCTTCCAATCCACGGGG CGGCATCCAGCAAGCCTTTGTTTTCTATAACAAATCCA CATTTTGACCTCGGATCAGGTAGGGATACCCGCTGAA CTTAAGCATATCAA

\section{Exserohilum rostratum AUMC 14374 (MT071832) (Length: 588)}

TGCGGAGGGATCATTACACAACAAAAATATGAGGGTGT GGTTTGCTGGCAACAGCGTCCGCCCCAAGTATTTTTC ACCCATGTCTTTTGCGCACTTTTTGTTTCCTGGGCGAG TTCGCTCGCCACCAGGACCCAACCATAAACCTTTTTTT ATGCAGTTGCAATCAGCGTCAGTATAATAATTCAATTTA TTAAAACTTTCAACAACGGATCTCTTGGTTCTGGCATC GATGAAGAACGCAGCGAAATGCGATACGTAGTGTGAA TTGCAGAATTCAGTGAATCATCGAATCTTTGAACGCAC ATTGCGCCCTTTGGTATTCCAAAGGGCATGCCTGTTC GAGCGTCATTTGTACCCTCAAGCTTTGCTTGGTGTTG
GGCGTCTTTTTGTCTCTCCCCTTGTTGGGGGAGACTC GCCTTAAAACGATTGGCAGCCGACCTACTGGTTTTCG GAGCGCAGCACAAATTTGCGCCTTCCAATCCACGGGG CGGCATCCAGCAAGCCTTTGTTTTCTATAACAAATCCA CATTTTGACCTCGGATCAGGTAGGGATACCCGCTGAA CTTAAGCATATCAATAAGCGGAGGA

\section{Exserohilum rostratum AUMC14375 (MT071834) (Length: 574bp)}

GCGGAGGGATCATTACACAACAAAAATATGAGGGTGT GGTTTGCTGGCAACAGCGTCCGCCCCAAGTATTTTTC ACCCATGTCTTTTGCGCACTTTTTGTTTCCTGGGCGAG TTCGCTCGCCACCAGGACCCAACCATAAACCTTTTTTT ATGCAGTTGCAATCAGCGTCAGTATAATAATTCAATTTA TTAAAACTTTCAACAACGGATCTCTTGGTTCTGGCATC GATGAAGAACGCAGCGAAATGCGATACGTAGTGTGAA TTGCAGAATTCAGTGAATCATCGAATCTTTGAACGCAC ATTGCGCCCTTTGGTATTCCAAAGGGCATGCCTGTTC GAGCGTCATTTGTACCCTCAAGCTTTGCTTGGTGTTG GGCGTCTTTTTGTCTCTCCCCTTGTTGGGGGAGACTC GCCTTAAAACGATTGGCAGCCGACCTACTGGTTTTCG GAGCGCAGCACAAATTTGCGCCTTCCAATCCACGGGG CGGCATCCAGCAAGCCTTTGTTTTCTATAACAAATCCA CATTTTGACCTCGGATCAGGTAGGGATACCCGCTGAA CTTAAGCATATC

\section{Pathogenicity}

Cultivar of bean (Giza 6) was used to compare five isolates of $E$. rostratum (AUMC 14371, AUMC 14372, AUMC 14373, AUMC 14374 and AUMC 14371). These isolates collected from ElWasta, Nasser, Beni Sweif, Sumosta and Beba respectively in Beni Sweif governorate. Data observed in Table 2 revealed that, isolate (AUMC 14371) recorded lowest effect of disease incidence 26.3\% however isolate (AUMC 14375) obtained from Beba was scored the highest of bean blight disease incidence $36.7 \%$. These symptoms were similar to the characteristic lesions of bean blight that were observed in the field. The re-isolated fungal cultures from the artificially infected leaf lesions showed the same morphological characteristics as the inocula, fulfilling Koch's postulates.

Table 2: Pathogenicity test of E. rostratum isolates on bean plants (var. Giza 6).

\begin{tabular}{lll}
\hline $\mathbf{N}$ & Isolates & Disease incidence \% \\
\hline 1 & AUMC 14371 & 26.3 \\
\hline 2 & AUMC 14372 & 34.0 \\
\hline 3 & AUMC 14373 & 29.0 \\
\hline 4 & AUMC 14374 & 32.0 \\
\hline 5 & AUMC 14375 & 36.7 \\
\hline L.S.D 0.05 & 3.8 \\
\hline
\end{tabular}




\section{Host range}

Data presented in Table 3 demonstrate six plant hosts namely Tomato, Pepper, Potato, Watermelon, squash in addition to Bean, showed distinct disease responses upon inoculation with E. rostratum. Irregular gray patches are formed on leaves and pods, which finally cover the whole leaf surface and young stems. In comparison with egg plant, soybean, cowpea, muskmelon, and cucumber which showed no visible infection. Under favorable environmental conditions for disease development symptoms. Finally, the lesions become necrotic and the whole leaves die.

Table 3: Susceptibility of various species infection by Exserohilum rostratum.

\begin{tabular}{|c|c|c|c|}
\hline $\mathbf{N}$ & Family & $\begin{array}{l}\text { Plant species, } \\
\text { Common name }\end{array}$ & $\begin{array}{l}\text { Disease } \\
\text { reaction }\end{array}$ \\
\hline \multirow{4}{*}{1} & \multirow{4}{*}{ Solanaceae } & $\begin{array}{l}\text { Solanum melongena } \mathrm{L} \text { in } \\
\text { Egg plant }\end{array}$ & - \\
\hline & & $\begin{array}{l}\text { Lycopersicon esculentum Mill. } \\
\text { Tomato }\end{array}$ & + \\
\hline & & $\begin{array}{l}\text { Capsicum annuum Linn. } \\
\text { Pepper }\end{array}$ & + \\
\hline & & $\begin{array}{l}\text { Solanum tuberosum Linn. } \\
\text { Potato }\end{array}$ & + \\
\hline \multirow{3}{*}{2} & \multirow{3}{*}{ Fabaceae } & $\begin{array}{l}\text { Phaseolus vulgaris } \\
\text { Common bean }\end{array}$ & + \\
\hline & & $\begin{array}{l}\text { Glycine max } \\
\text { Soybean }\end{array}$ & \\
\hline & & $\begin{array}{l}\text { Vigna unguiculata sub sp. } \\
\text { unguculata } \\
\text { Cowpea }\end{array}$ & - \\
\hline \multirow{4}{*}{3} & \multirow{4}{*}{ Cucurbitaceae } & $\begin{array}{l}\text { Cucumis melo Naud } \\
\text { Muskmelon }\end{array}$ & \\
\hline & & $\begin{array}{l}\text { Cucurbita pepo L. } \\
\text { Squash }\end{array}$ & + \\
\hline & & $\begin{array}{l}\text { Citrullus lanatus } \\
\text { Watermelon }\end{array}$ & + \\
\hline & & $\begin{array}{l}\text { Cucumis sativus L. } \\
\text { Cucumber }\end{array}$ & - \\
\hline 4 & Brassicaceae & $\begin{array}{l}\text { Brassica oleracea var. Capitata } \\
\text { Cabbage }\end{array}$ & - \\
\hline
\end{tabular}

\section{Effect of temperature}

Effect of temperature levels on spore germination from $5-55^{\circ} \mathrm{C}$ (Table 4) as were used to study the effect of temperature on conidial germination in the presence of high relative humidity. Data revealed that conidia are able to germinate in a wide temperature range. The average of spore germination was the highest after 48 hours incubation $(61.9 \%)$ at $35^{\circ} \mathrm{C}$. meanwhile the germination was not recorded at $55^{\circ} \mathrm{C}$ even after 48 hours incubation. On the other hand, the lowest spore germination as $2.7 \%$ on the average at $5^{\circ} \mathrm{C}$.

Table 4: Effect of temperature on spore germination of E. rostratum.

\begin{tabular}{lllll}
\hline & \multirow{2}{*}{$\begin{array}{l}\text { Temperature } \\
\text { (A) }\end{array}$} & \multicolumn{3}{l}{ Spore germination $\%$} \\
\cline { 3 - 5 } & \multicolumn{3}{l}{ Incubation period (B) } \\
\hline 1 & & $24 \mathrm{~h}$ & $48 \mathrm{~h}$ & Mean(A) \\
\hline 2 & $5^{\circ} \mathrm{C}$ & 1.7 & 6.3 & 2.7 \\
\hline 3 & $10^{\circ} \mathrm{C}$ & 4.7 & 12.0 & 5.6 \\
\hline 4 & $15^{\circ} \mathrm{C}$ & 18.0 & 39.0 & 19.0 \\
\hline 5 & $20^{\circ} \mathrm{C}$ & 31.0 & 56.0 & 29.0 \\
\hline 6 & $25^{\circ} \mathrm{C}$ & 32.7 & 67.7 & 33.4 \\
\hline 7 & $30^{\circ} \mathrm{C}$ & 45.0 & 91.0 & 45.4 \\
\hline 8 & $35^{\circ} \mathrm{C}$ & 86.7 & 99.0 & 61.9 \\
\hline 9 & $40^{\circ} \mathrm{C}$ & 61.7 & 88.0 & 49.9 \\
\hline 10 & $45^{\circ} \mathrm{C}$ & 21.7 & 39.3 & 20.3 \\
\hline 11 & $50^{\circ} \mathrm{C}$ & 3.0 & 9.0 & 4.0 \\
\hline 12 & $55^{\circ} \mathrm{C}$ & 0.0 & 0.0 & 0.0 \\
\hline $\mathrm{Mean}(\mathrm{B})$ & 27.8 & 46.1 & - \\
\hline $\mathrm{LSD}$ at $5 \%$ & $\mathrm{~A}=2.9 \mathrm{~B}=1.5 \mathrm{AB}=5.0$ & \\
\hline & & & & \\
\hline
\end{tabular}

\section{DISCUSSION}

In this study, the fungus isolated from infected bean leaves with seedling blight symptoms was identified as Exserohilum rostratum based on morphology and the phylogenietic properties based on ITS1 andIT4 that placed all isolates in the same clade with high support and apart from the other Exserohilum or Setosphaeria species. There was no significant variation in ITS and IT4 sequences among the Exserohilum rostratum isolates collected from different localities throughout Beni Sweif governorate, 
Egypt and were added to the GeneBank with new accession number..

Pathogenicity tests showed that Exserohilum rostratumis able to make a significant impact on bean productivity at this time, especially, the pathogen can infect and cause the disease in a wide range of temperatureand altering agronomic practices, climate change or the appearance of virulent genotypes [26,27].

Exserohilum holmii, originally described as Helminthosporium, was the cause of leaf blight of Dactyloctenium aegyptium in Georgia, USA. Luttrell [13] obtained the sexual morph in culture by mating compatible conidial strains on Sach's agar supporting sterilized barley grains.

Exserohilum rostratum is by far the most commonly recorded and known species of the genus. This cosmopolitan species has been recorded from numerous hosts, especially Poaceae and other monocots, causing leaf spot and foot rot of wheat and other grasses, blight, damping-off, rots including leaf spot of banana $[19,28]$. All these symptoms and several hosts correspond to our results in the host range test with infection in plant species belong to Solanaceae, Fabaceae, and Cucurbitaceae. At any rate, knowledge about bean blight and the causal pathogen of thr disease in Egypt is still scanty and uncertain and needs more further studies.

E. rostratum is a fungus with a broad ecological niche and shows considerable diversity in nature. The fungus causes disease symptoms on more than 30 plant species covering 28 genera in 11 families, including many economically important crops such as corn, rice, sugarcane, sweet sorghum, tomato and wheat [29-33]. In some cases, E. rostratumis known to cause severe yield losses, for example, corn seed infection has been recorded at the rate of $85 \%$ and corn leaf incidence up to $18 \%$ [30,34]. Eight plant species have been reported as natural hosts of $E$. rostratumin China [35,36], while approximately another 20 plant species were confirmed to be hosts of E. rostratum through artificial inoculations [37]. E. rostratum was found to be the causal agent of leaf blight of the ornamental plant Caryota mitis Loureiro (Arecaceae) in Argentina [38], leaf spot of tiger grass Thysanolaena maxima (Roxb.) Kuntze in South Florida [39], boll and lint rot disease of cotton in Nehbandan region, South Khorasan, Iran [40], banana leaf spot in China [20] and leaf spot diseases of pineapple in china [41]. In south western Iran, a new sugarcane leaf spot disease caused by E. rostratum was reported by Ahmedpour et al. [42]. E. rostratum was recorded to be associated with leaf spot of rice in Malaysia [43,44] and a pathogen of rice brown spot in Pakistan [45]. E. rostratum has been reported as causal agent of leaf spots on Zea mays, Ananas comosus, Musa paradisiaca and Hevea brasiliensis in China [46].

In reports from India, Choudhary et al., showed that E. rostratum was responsible for leaf spot disease of Lagenaria siceraria (a medicinal and nutritious domesticated cucurbit vegetable named as Bottle gourd) [47]. More recently E. rostratum was recorded as a cause of Petal Spot of Phalaenopsis Orchid in Taiwan [48].

In Egypt, E. rostratum was reported a rare fungus from the phyllosphere and phylloplane fungi of broad bean leaves [49] and was less frequently isolated from the air over banana plantations [50]. Moreover, E. rostratum was recorded among the endophytic fungi of the Red Sea aquatic plant Avicennia marina [51] and was considered a causal pathogen of lettuce root rot in combination with Fusarium oxysorum [52].

\section{CONCLUSION}

As the authors are far aware, there is no available information on bean blight disease and also Exserohilum rostratum, the causative of the disease, was isolated herein from diseased common bean plants for the first time in Egypt.

\section{ACKNOWLEDGEMENTS}

I am greatly thankful to Dr. A.M. Moharram, Director of Assiut University Mycological Centre for his kind help, moral support and wise guidance comments. And checking morphological and molecular identification of the fungal strains beside reviewed this article.

\section{REFERENCES}

1. Hadi H, Kazem GG, Farrokh K, Mostafa V, Mohammed S. Response of common bean (Phaeseolus vulgaris L.) to different levels of shade. J Argon. 2006;5:595-599.

2. Link HF. Observationes in ordines plantarum naturales. Dissertatio I. Magazin der Gesellschaft Naturforschenden Freunde Berlin 1809;3:3-42.

3. Seifert K. Morgan-Jones G, Gams W. The genera of hyphomycetes. CBS Biodiversity Series 9. CBS-KNAW Fungal Biodiversity Centre, Utrecht. 2011;1-32.

4. Tanaka K, Hirayama K, Yonezawa H. Revision of the Massarineae (Pleosporales, Dothideomycetes). Studies in Mycology 2015;82:75-136.

5. Voglmayr H, Jaklitsch WM. Corynespora, Exserohilum and Helminthosporium revisited - New species and generic reclassification. Studies in Mycology 2017;87:43-76.

6. Shoemaker RA. Nomenclature of Drechslera and Bipolaris, grass parasites segregated from 'Helminthosporium. Canadian Journal of Botany. 1959;37:879-887.

7. Drechsler C. Phytopathological and taxonomic aspects of Ophiobolus, Pyrenophoraand Helminthosporium and a new genus, Cochliobolus. Phytopathology. 1934:24:953-983.

8. Nelson RR. The perfect stage of Helminthosporium cynodontis. Mycologia. 1964;56:64-69.

9. Alcorn JL. Cochliobolus ellisii sp. nov. Transactions of the British Mycological Society. 1983;81:172-174.

10. Alcorn JL. Cochliobolus heliconiae sp. nov. Australian Systematic Botany. 1996;9:813-817.

11. Manamgoda DS. Cai L, Bahkali AH. Cochliobolus: an overview and current status of species. Fungal Diversity. 2011;51:3-42.

12. Luttrell ES. The perfect stage of Helminthosporium turcicum. Phytopathology. 1958;48:281-287.

13. Luttrell ES. A Trichometasphaeria perfect stage of a Helminthosporium causing leaf blight of Dactyloctenium. Phytopathology. 1963;53:281-285.

14. Nelson RR. The perfect stage of Helminthosporium pedicellatum. Mycologia. 1965;57:665-668.

15. Leonard KJ, Suggs EG. Setosphaeriaprolata, the ascigerous state of Exserohilum prolatum. Mycologia 1974;66:281-297. 
16. Rossman AY, Crous PW, Hyde KD. Recommended names for pleomorphic genera in Dothideomycetes. IMA Fungus. 2015;6:507-523.

17. McNeill J, Barrie FF, Buck WR, International Code of Nomenclature for algae, fungi, and plants(Melbourne Code). Koeltz Scientific Books, Königstein (Regnum Vegetabile. 2012;154.

18. Sivanesan A. New species of Exserohilum. Transactions of the British Mycological Society. 1984;83:319-329.

19. Sivanesan A. Graminicolous species of Bipolaris, Curvularia, Drechslera, Exserohilum and their teleomorphs. Mycological Papers. 1987;158:1-261.

20. 20. Lin SH, Huang SL, Li QQ,Hu CJ,Fu G, Qin LP, et al. Characterization of Exserohilum rostratum, a new causal agent of banana leaf spot disease in China Australasian Plant Pathol. 2011 40:246-259.

21. Pitt JI, Hocking AD. Fungi and Food Spoilage, Blackie Academic and Professional, London 3rd Ed. 2009;20.

22. Domsch KH, Gams W, Anderson TH. Compendium of soil fungi. IHW-Verlag, Eching 2nd Ed. 2007;692.

23. White TJ, Bruns T, Lee S, Taylor J. Amplification and direct sequencing of fungal ribosomal RNA genes for phylogenetics. In PCR Protocols: A guide to Methods and Applications (ed. M.A. Innis, DH. Gelfand, JJ. Sninsky \& TJ. White). 1990;315-322.

24. Whipps JM, Budge SP, Fenton JS. Characteristics and host range of tomato powdery mildew. Plant Pathology. 1998;47:36-48.

25. Snedecor GW, Cochran WG. Statistical Methods. 8thedn. Iowa State Univ. Press, Ames, Iowa, USA. 1989;251.

26. Brunelli KR, Dunkle LD, Sobrinho CA, Fazza AC, Camargo LEA. Molecular variability in the maize grey leaf spot pathogens in Brazil. Genet Mol Biol. 2008;31:938-942.

27. Reddy PP. Climate resilient agriculture for ensuring food security. New Delhi: Springer, India. 2015;373.

28. Farr DF, Rossman AY. Fungal databases, U.S. National Fungus Col-lections, ARS, USDA. 2001.

29. Zummo N. Red spot (Helminthosporium rostratum) of sweet sorghum and sugarcane, a new disease resembling anthracnose and red rot. Plant Dis. 1986;70:800.

30. Leonard KJ, Thakur RP, Leath S. Incidence of Bipolaris and Exserohilum species in corn leaves in North Carolina. Plant Dis. 1988;72:1034-1038.

31. Okoli CAN, Erinle ID. Comparative rate of rot-induction by nine fungal pathogens on stored tomato fruits in Nigeria. J Stored Prod Res. 1990;26:77-79.

32. Luan FG, Qiang S, Ma DY, Riziwangguli P. The primary studies on isolation and identification of wheat black embryo in Xinjiang. Xinjiang Agric Sci. 2004;41(5):357-360.

33. Cardona R, Gonzalez MS. First report of Exserohilum rostratum associated with rice seed in Venezuela. Plant Dis. 2007;91:226.

34. McGee DC. Seed borne and seed-transmitted diseases of maize in rice-based cropping systems. In: International Rice Research Institute (ed) Rice seed health-Proceedings of the international workshop on rice seed health, 1987. IRRI, Manila. 1988;203-213.

35. Sun GY, Zhang R, Zhang HY, Zhang TY. Identification of some Helminthosporia fungi from Taiwan province. Acta Agric Bor-Occid Sin. 1997;6(1):92-93.
36. Tsai JN, Tsai WH, Chen JL. Pathogenicity of Exserohilum rostratum on corn and weeds in the corn fields. Plant Pathol Bull. 2001;10:181-186.

37. Chandramohan S, Charudattan R. Control of seven grasses with a mixture of three fungal pathogens with restricted host ranges. Biol Control. 2001;22:246-255.

38. Cúndom MA, Gutiérrez SA, Cejas P, Cabrera MG. Exserohilum rostratum on Caryota mitis in Argentina Summa Phytopathologica. 2006;32:277-279.

39. Brunings AM, Datnoff LE, Palmateer, AJ, Locke JC, Krause CR. Exserohilum leaf spot on tiger grass. Online. Plant Health Progress. 2009.

40. Mirzaee MR, Zare R, Heydari A. First report of boll and lint rot disease of cotton caused by Exserohilum rostratum in Iran Journal of Plant Pathology. 2010;92:107-122.

41. Luo ZW, He F, Fan HY, Wang XH, Hua M. First report of leaf spot disease caused by Exserohilumrostratum on pine apple in Hainan province, China. Plant Disease 2012; 96: 458.

42. Ahmadpour A, Karami S, Heidarian Z, Javan-Nikkhah M. Exserohilum rostratum causing sugarcane leaf spot in Iran Australasian Plant Diseases Notes. 2013;8:97-99.

43. Kusai, NA. Phenotypic, molecular and mating type analyses of Exserohilum rostratum associated with leaf spot of rice M. Sc. Thesis, School of Graduate Studies, University of Putra, Malaysia 2015.

44. Toher AS, Ahmad ZA, Wong MY. First report of Exserohilum rostratum as pathogen of rice brown spot in Malaysia. Plant Disease. 2016;100:226-226.

45. Majeed RA, Shahid AA, Liaqat GA, Saleem, K, AsifM, Shafiq M, et al. First report of Setosphaeria rostrata causing brown leaf spot of rice in Pakistan. Plant Disease 2016;100(11):2162-2163.

46. Liu YX, Shi YP, CaiZY. A first report of rubber tree leaf spotcaused by Exserohilum rostratum in China Plant Disease. 2016;100:2167.

47. Choudhary M, Sardana HR, Bhat MN, Gurjar MS. First report of leaf spot diseases caused byExserohilumrostratum on bottle gourd in India FirstPlant Disease. 2018;102:2042-2042.

48. Huang CW, Huang JH, Tsai JN, Chung LH, Hsieh TF. Petal spot of Phalaenopsis caused by Exserohilum rostratum. J Taiwan Agric Res. 2019;68:47-58.

49. El-Said AHM, Saleem A, Maghraby TA, Hussein MA. Cellulase activity of some phytopathogenic fungi isolated from diseased leaves of broad bean. International Journal of Current Microbiology and Applied Science. 2014;883-900.

50. Moubasher AH, Moharram AM, Ismail MA, Abdel-Hafeez MH. Aeromycobiota over banana plantations in Assiut Governorate and .enzymatic producing potential of the most common species Journal of Basic \& Applied Mycology (Egypt). 2016;7:9-18.

51. Basheer MA, Mekawy AA, El Kafrawy SB, Abouzeid MA. Antimicrobial activities of endophytic fungi of Red Sea aquatic plant Avicennia marina Egyptian Journal of Botany. 2018;53:231-240.

52. Alamri AAM., Hashem M, Mostafa YS, Nafady NA, Abo-Elyousr KA M. Biological control of root rot in lettuce caused by Exserohilum rostratum and Fusarium oxysporum via induction of the defense mechanism. Biologica Control. 2019;128:76-84. 